\title{
Demographic and etiologic characteristics of children with traumatic serious hyphema
}

\author{
Çocuklarda travmatik ciddi hifemalarda \\ demografik ve etyolojik özellikler
}

\author{
Fatih Mehmet TÜRKCÜ, Harun YÜKSEL, Alparslan ŞAHİN, Kürşat CİNGÜ, Şeyhmus ARI, \\ Yasin ÇINAR, Muhammed ŞAHİN, Adnan YILDIRIM, İhsan ÇAÇA
}

\section{BACKGROUND}

We aimed to evaluate the etiologic factors, complications, follow-up, and treatment outcomes in serious hyphema following blunt ocular trauma in childhood.

\section{METHODS}

The medical records of 136 patients diagnosed as grade 3 or 4 hyphema due to blunt ocular trauma between January 2006 and December 2011 were evaluated. Visual acuity (VA), complications, and medical and surgical treatments were analyzed. Factors affecting visual prognosis were compared in grade 3 and 4 hyphema cases.

\section{RESULTS}

The mean age of patients was $9.7 \pm 4$ years. Etiologic factors for trauma were stone in $53(39 \%)$, bead bullet in 25 $(18.4 \%)$ and others in $58(42.6 \%)$ patients. The most common complication of grade 3 and 4 hyphema was traumatic mydriasis $(19.1 \%)$, followed by cataract $(9.6 \%)$ and glaucoma $(5.1 \%)$. Medical treatment was successful in 114 $(83.8 \%)$ patients, and $22(16.2 \%)$ patients underwent surgery. Mean initial and final VA of grade 4 patients were found to be significantly lower than those of grade 3 patients.

\section{CONCLUSION}

In grade 3 and 4 hyphema due to blunt trauma, visual prognosis worsened in the presence of additional ocular pathologies. Considering the bad visual prognosis of severe hyphema patients, prompt treatment and close follow-up may prevent complications resulting in poor VA.

Key Words: Blunt trauma; children; hyphema; visual prognosis.

\section{$\boldsymbol{A M A C}$}

Çocuk yaş grubunda künt göz travmaları sonrası oluşan ciddi hifemalarda etyolojik faktörler, oluşan komplikasyonlar, takip ve tedavi sonuçları değerlendirildi.

\section{GEREÇ VE YÖNTEM}

Ocak 2006 ile Aralık 2011 yılları arasında künt göz travması nedeni ile evre 3 ve 4 hifema tanısı alan ve tedavisi yapılmış 136 hastanın dosyası geriye dönük olarak incelendi. Görme keskinliği (GK), gözlenen komplikasyonlar, uygulanan medikal ve cerrahi tedaviler kaydedildi. Evre 3 ve 4 olgularda görme prognozu üzerinde etkili faktörler ve tedavi sonuçları karşılaştırıldı.

\section{BULGULAR}

Hastaların yaş ortalamaları 9,7 \pm 4 yıl idi. Travmaya sebep olan etyolojik faktörler sırası ile taş çarpması 53 (\%39), boncuk mermisi $25(\% 18,4)$ ve diğer faktörler $58(\% 42,6)$ oluşturmakta idi. Evre 3 ve 4 hifemanın en sik komplikasyonu travmatik midriyazis $(\% 19,1)$ iken bunu katarakt $(\% 9,6)$ ve glokom $(\% 5,1)$ izlemekteydi. İlaç tedavisi 114 $(\% 83,8)$ olguda başarılı olurken, $22(\% 16,2)$ olguda cerrahi gerekti. İlk ve son GK evre 4 olgularda evre 3 'lere göre belirgin olarak daha düşüktü.

\section{SONUÇ}

Künt travma nedeni ile hifema gelişen evre 3 ve 4 olgularda ilave göz patolojileri nedeni ile görme prognozu olumsuz etkilenebilmektedir. Ciddi hifemalı olgularda görme prognozundaki olumsuz seyir göz önüne alınarak bu hastaların yakın takibi ve tedavisi oluşabilecek komplikasyonların kalicı etkilerini önleyebilecektir.

Anahtar Sözcükler: Künt travma; çocuk; hifema; görme prognozu.
Presented at the 46th National Congress of Ophthalmology Society (October 17-21, 2012, Antalya Turkey).

Department of Ophthalmology, Dicle University Faculty of Medicine, Diyarbakir, Turkey.
TOD 46. Ulusal Kongresi'nde sunulmuștur (17-21 Ekim 2012, Antalya).

Dicle Üniversitesi Tıp Fakültesi, Göz Hastalıkları Anabilim Dalı, Diyarbakır. 
Hyphema is the presence of red blood cells in the anterior chamber of the eye. ${ }^{[1]}$ Since the most common causes are blunt or penetrating ocular trauma, it may also develop following surgeries, or can occur spontaneously related to some systemic disorders. ${ }^{[1-3]}$ In addition to congenital causes, the most common cause of unilateral blindness in childhood is ocular trauma. ${ }^{[4]}$ Ocular trauma is more common in developing countries, and blunt trauma often leads to hyphema. ${ }^{[5]}$

Sudden compression and distortion of ocular structures following contusion has been considered the main reason associated with the development of hyphema. Anterior chamber bleeding occurs as a result of a ruptured vessel in the peripheral iris and anterior ciliary body due to stretching of limbal tissues. ${ }^{[6,7]}$

The majority of patients with hyphema can be treated without any ocular complications. Accompanying complications such as increased intraocular pressure (IOP), re-bleeding, corneal blood staining, cataract, intravitreal hemorrhage, choroid rupture, sphincter tear, and iridodialysis may affect the visual prognosis. $^{[1,2,7-9]}$ The main causes of increased IOP are angle obstruction with blood cells, posterior synechia formation and angle recession. ${ }^{[10]}$

Apart from complications of traumatic hyphema, other simultaneous findings (cataract, intravitreal hemorrhage, choroid rupture, sphincter tear, iridodialysis) stemming from the trauma are important for visual prognosis. ${ }^{[7-9]}$

The aim of the present study was to investigate the demographic and clinical characteristics of grade 3 and 4 hyphema in pediatric patients.

\section{MATERIALS AND METHODS}

Ethical approval was obtained from the Dicle University local ethics committee. Of the total number of 420 patients who were diagnosed as hyphema in Dicle University Department of Ophthalmology between January 2006 and December 2011, medical records of 136 pediatric patients were evaluated retrospectively.

The patients' age, gender, affected eye, additional ocular pathologies, systemic diseases, and treatments were recorded.

The patients were classified according to the Agapitos et al. ${ }^{[11]}$ classification. A total of 136 children with grade 3 (hyphema from $1 / 2$ to near total in anterior chamber) or grade 4 (total hyphema) hyphema were enrolled in the study.

Patients with grades 1 and 2 hyphema, systemic diseases like diabetes mellitus, sickle cell anemia, kidney and/or liver diseases, penetrating eye trauma, use of anticoagulants, or age above 18 years were excluded.
At the time of admission, patients' visual acuity (VA) based on Snellen's chart, IOP measurements by Goldmann's applanation tonometry and Tonopen (if applanation tonometry could not be applied to young children), and anterior segment and fundus examination findings were recorded. B-mode ocular ultrasonography was performed in patients who had total hyphema, traumatic cataract and/or vitreous hemorrhage.

All patients were hospitalized for treatment. As the standard therapy, all patients received topical prednisolone acetate $1 \%$ eye drops (Predforte, Allergan, Irvine, CA) 8 times daily and topical cyclopentolate hydrochloride $1 \%$ eye drop (Sikloplejin, Abdi İbrahim, Turkey) 2 times daily. They were followed up with bed rest, with the head of the bed elevated. Patients with IOP levels higher than $21 \mathrm{mmHg}$ received timolol maleate (Timoptic, Merck, Sharpe \& Dohme, West Point, PA) 2 times daily. For patients with uncontrolled IOP, dorzolamide + timolol maleate combination (Cosopt, Merck \& Co, Inc., Whitehouse Station, NJ) 2 times daily and oral acetazolamide (Diazomid, Sanofi, Turkey) 2 times daily were added to the treatments.

In patients who had total anterior chamber hyphema, uncontrolled IOP, and corneal blood staining, hemorrhage was cleaned by anterior chamber lavage. During follow-up examinations, presence of fresh blood elements in the anterior chamber was accepted as recurrence of hemorrhage. The last examinations were done after total clearance of the hyphema in uncomplicated cases or after the treatment of complications in complicated cases. During the last visit examination, VA, IOP, and anterior and posterior segment complications were recorded.

Statistical analyses were performed using the Statistical Package for the Social Sciences program (SPSS 15.0 Inc, Chicago, USA). To check for normal distribution, the Kolmogorov-Smirnov test was performed. Student's t-test and one-way ANOVA test were used to compare the parameters with normal distribution. Mann-Whitney U and Kruskal-Wallis tests were used to compare nonparametric parameters. Categorical data were analyzed with the chi-square or the Fisher exact test.

\section{RESULTS}

The mean ages of grade 3 and 4 patients were $10.1 \pm 3.8$ and $9.3 \pm 4.0$ years, respectively (range, $1-18$ years, $p>0.05$ ). There was no significant difference between grade 3 and 4 patients in terms of the mean age. The patients were mostly distributed in the age interval of 7-12 years (39.7\%) (Fig. 1). The number of male subjects $(80.1 \%)$ was significantly higher than of female (19.9\%) subjects (4:1). Sixty-four (47.1\%) patients had trauma to their right eye and $72(52.9 \%)$ to their left eye. None of the patients had bilateral hyphema. 


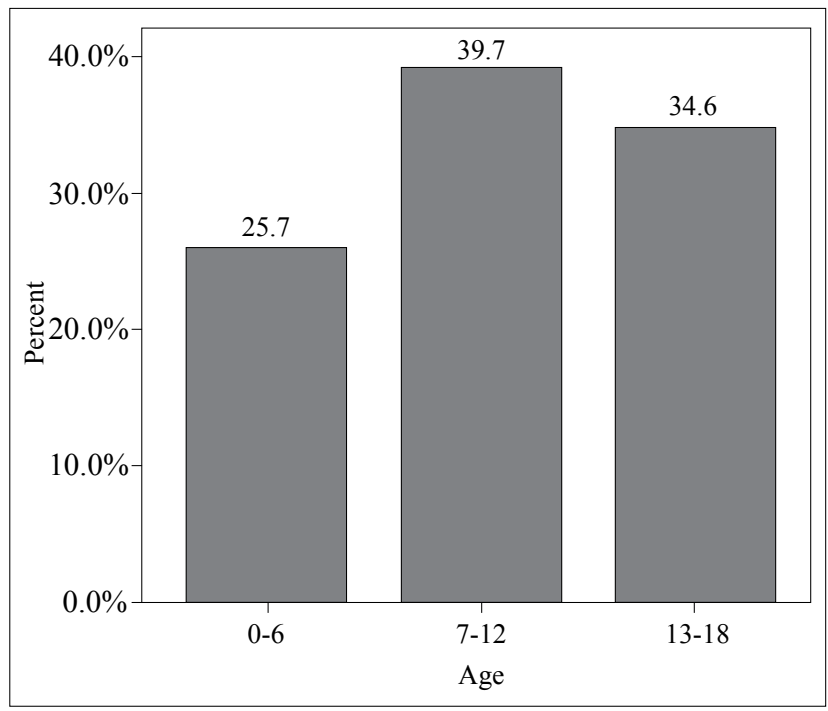

Fig. 1. Distribution of the patients according to age.

Etiologic factors for trauma were stone in 53 (39\%), bead bullet (toy gun) in $25(18.4 \%)$ and others in $58(42.6 \%)$ patients (Fig. 2). There was no significant relationship between the etiologic factors and VA, IOP and recurrence of hyphema ( $>0.05)$. When the patients were grouped according to intensity of the hyphema, $38.2 \%$ were grade 3 and $61.8 \%$ were grade 4 . The frequency of grade 4 hyphema was significantly lower in bead bullet (toy gun)-induced hyphema when compared to stone or other etiologic reasons (Fig. 3, $\mathrm{p}=0.046$ ).

The most frequent accompanying symptoms to hyphema were corneal epithelial defect (49.3\%) and rise in IOP higher than $21 \mathrm{mmHg}(35 \%)$ during the first admission to the hospital (Table 1).

The mean initial VA of the patients was $0.13 \pm 0.22$. During the follow-up period, the mean VA increased to $0.81 \pm 0.32$. Fifteen percent of the patients had a final VA less than 0.5 and $6 \%$ of the patients had a final VA less than 0.1. Both initial and final VA and IOP were found to be lower in grade 4 patients than in grade 3 patients (Table 4). The most common complication was traumatic mydriasis $(19.1 \%)$, followed by cataract $(9.6 \%)$ and glaucoma (5.1\%) (Table 2). The complication profile was found to be similar between the grade 3 and 4 patients $(\mathrm{p}>0.05)$.

One hundred and twenty-three patients were followed up without any surgical intervention. One $(1.9 \%)$ patient in the grade 3 group and $12(9.6 \%)$ patients in the grade 4 group underwent surgery $(p=0.017)$. Need for surgery was higher in grade 4 patients. At the initial admission, $11(8.1 \%)$ patients needed anterior chamber lavage and $2(1.5 \%)$ patients needed conjunctival exploration surgeries. There was no significant relationship between the etiology of trauma and need for surgery $(\mathrm{p}=0.751)$.

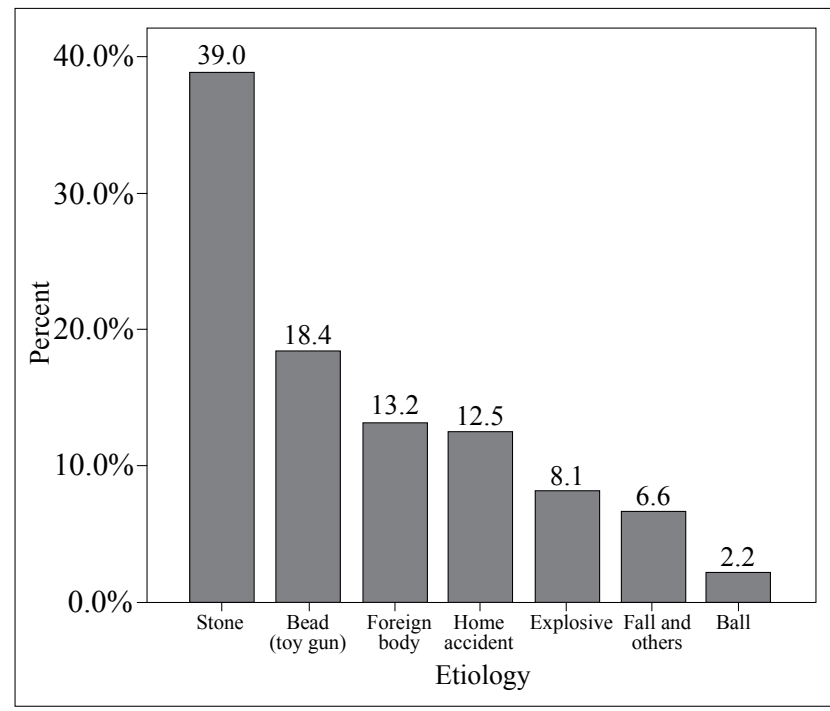

Fig. 2. Distribution of the etiologic factors leading hyphema.

In the follow-up period, $114(83.8 \%)$ patients responded to the medical treatment, whereas 22 cases underwent surgery due to complications. The most common surgical intervention was cataract surgery (4.4\%) followed by trabeculectomy (4.4\%) (Table 3 ). Etiological factors were similar in grades 3 and 4 hyphema.

Recurrent bleeding occurred in 9 patients. However, there was no significant relationship between recurrent bleeding and hyphema grade or etiology of the trauma ( $\mathrm{p}>0.05)$.

\section{DISCUSSION}

The frequency of hyphema is 17-20/100.000 in the general population. In children, the most common finding following ocular trauma is hyphema, and it occurs in $32 \%$ of all traumas. ${ }^{[11,12]}$ Hyphema develops mostly

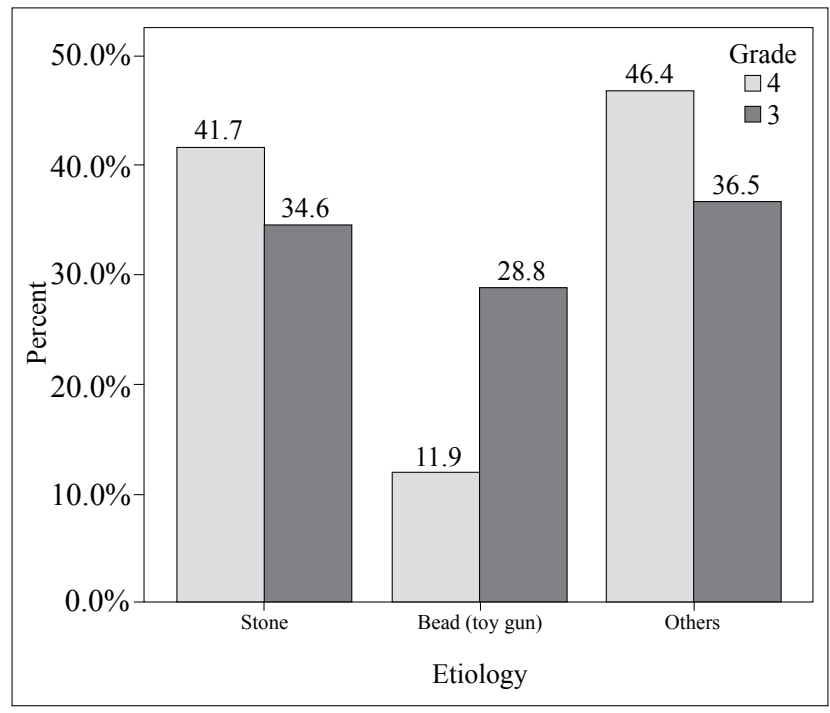

Fig. 3. Distribution of the etiologic factors according to severity of hyphema. 
Table 1. Frequency of the accompanying findings of hyphema

\begin{tabular}{lcc}
\hline & \multicolumn{2}{c}{ Frequency (Percent) } \\
\cline { 2 - 3 } & $\mathrm{n}$ & $\%$ \\
\hline No additional finding & 42 & 30.9 \\
Corneal epithelial defect & 67 & 49.3 \\
Intraocular pressure increase & 48 & 35.3 \\
Iridodialysis & 6 & 4.4 \\
Cataract & 1 & 0.7 \\
Vitreus hemorrhage & 5 & 3.7 \\
Retinal hemorrhage & 6 & 4.4 \\
Retinal detachment & 1 & 0.7 \\
Macular edema & 2 & 1.5 \\
Eyelid laceration & 6 & 4.4 \\
\hline
\end{tabular}

following a blunt ocular trauma, and two-thirds of the patients are male subjects. ${ }^{[13,14]}$ Previous studies have included all age groups and all grades. ${ }^{[11,14,15]}$ As our hospital is the largest health center of the region, we reached the records of 136 children with grades 3 and 4 hyphema. To the best of our knowledge, this is the first study that has evaluated traumatic serious hyphema in pediatric patients. In contrast to the previous studies, we aimed to determine accompanying ocular pathologies, complications, need for surgery, and surgical outcomes in pediatric patients with grades 3 and 4 hyphema.

Hyphema resulting from blunt eye trauma may be seen in all age groups, but it has been reported more commonly in children at $10-19$ years of age. ${ }^{[16,17]}$ In our study population, hyphema was most frequently seen (39.7\%) among the children between 7-12 years of age. The etiologic factors for blunt trauma in our study population were similar to those of previous studies..$^{[3,14,15,18]}$ Grade 4 hyphema was less frequent in
Table 2. Frequency of complications seen in hyphema

\begin{tabular}{lcc}
\hline & \multicolumn{2}{c}{ Frequency (Percent) } \\
\cline { 2 - 3 } & $\mathrm{n}$ & $\%$ \\
\hline None & 70 & 51.5 \\
Mydriasis & 26 & 19.1 \\
Cataract & 13 & 9.6 \\
Glaucoma & 7 & 5.1 \\
Macular edema & 5 & 3.7 \\
Vitreus hemorrhage & 4 & 2.9 \\
Iridodialysis & 4 & 2.9 \\
Nephelion & 4 & 2.9 \\
Macular hole & 1 & 0.7 \\
Choroidal rupture & 1 & 0.7 \\
Retinal detachment & 1 & 0.7 \\
\hline
\end{tabular}

bead bullet (toy gun) injuries (40\%) than in stone injuries $(66 \%)$ and in "other" injuries (62\%). This may be due to the smaller volume of bead bullets that may lead to milder injury.

Of the patients, $52.9 \%$ had trauma to their left eyes. In a previous study, the left eye was reported to have greater exposure to trauma, and this was explained as being due to right hand preference, which may lead to reflex protection of the other eye. ${ }^{[15]}$

Visual acuity usually decreases in patients with traumatic hyphema, especially more severally in grade 3 and 4 hyphemas. ${ }^{[14,19-22]}$ In our series, vision loss was more severe in grade 4 than grade 3 patients. The mean initial and final VA of grade 4 patients were found to be significantly lower than those of grade 3 patients. Lower initial VA in grade 4 hyphema patients is thought to be related to the level of blood inside the anterior chamber. However, for final VA, it is thought to be related with accompanying anterior and posterior

Table 3. Treatment distribution based on grading

\begin{tabular}{lcccccc}
\hline & Medical & Iridodialysis & Trab & PPV & Ac lavage & Cataract \\
\hline Grade & & & & & & \\
3 & 46 & 2 & 1 & 0, & 1 & 2 \\
4 & 68 & 2 & 5 & 3 & 2 & 4 \\
Total no. (\%) & $114(83.8)$ & $4(2.9)$ & $6(4.4)$ & $3(2.2)$ & $3(2.2)$ & $6(4.4)$ \\
\hline
\end{tabular}

PPV: Pars plana vitrectomy; Ac: Anterior chamber; Trab: Trabeculectomy.

Table 4. Visual acuity and intraocular pressure at admission and at the end of the follow-up period

\begin{tabular}{lcccc}
\hline & Initial VA & Final VA & IOP $(\mathrm{mmHg})$ & Final IOP \\
\hline Grade 3 & $0.201 \pm 0.233$ & $0.88 \pm 0.26$ & $15.4 \pm 6.8$ & $12.8 \pm 4.8$ \\
Grade 4 & $0.082 \pm 0.197$ & $0.77 \pm 0.34$ & $22.3 \pm 10.5$ & $14.05 \pm 5.1$ \\
$p$ & $<0.0001$ & 0.029 & $<0.0001$ & 0.041 \\
\hline
\end{tabular}

VA: Visual acuity; IOP: Intraocular pressure. 
segment complications like traumatic cataract, glaucoma, iridodialysis vitreus hemorrhage, macular edema, and retinal detachment, as previously reported. ${ }^{[1,19-24]}$ The results of the current study were similar to those of previous studies conducted on traumatic hyphemas in adults with respect to the frequency of complications. ${ }^{[1,4,14,18,22]}$

Increase in IOP is common in traumatic hyphema patients, especially in grades 3 and 4 . Read and Goldberg reported that IOP was higher than $25 \mathrm{mmHg}$ in $25 \%$ of the traumatic hyphema patients at admission. This is due to obstruction in the trabecular meshwork and increased incidence of pupillary block. ${ }^{[1,19,25]}$ In our study population, $35 \%$ of the patients had an IOP higher than $21 \mathrm{mmHg}$. In addition, initial and final IOP levels were significantly higher in grade 4 patients compared to grade 3 patients. Anti-glaucomatous topical treatment was started in patients with a high IOP level. Eleven patients underwent anterior chamber lavage because of uncontrolled IOP. One patient with grade 3 and 5 patients with grade 4 underwent trabeculectomy because of uncontrolled IOP with anti-glaucomatous medication and anterior chamber lavage. Intractable glaucoma may develop because of angle recession in these patients, which was reported at a rate of $6-10 \%$ in various studies. According to some reports, glaucoma may develop many years after the trauma. This may be explained by the long-term complications of mild iridocorneal angle injury. ${ }^{[1,25,26]}$

Topical steroids, cycloplegic agents, antifibrinolytics, systemic steroids, and systemic aminocaproic acid may be used in the treatment of traumatic hyphema of children. These treatment options enable clearance of blood from the anterior chamber and prevent recurrent bleeding. ${ }^{[27,28]}$ Hyphema was entirely resolved with topical steroids and cycloplegic agents in $83.8 \%$ (114) of our patients. Re-bleeding occurred in 9 patients (after medical treatment or surgical treatment), and 3 of them needed anterior chamber lavage. The rate of rebleeding in traumatic hyphema was reported as $4.1 \%$ $35 \%$ in different patient series. ${ }^{[14,16,20,21]}$ Re-bleeding usually occurs during clot retraction and fibrinolysis. Some studies found a correlation between re-bleeding and the severity of the initial bleeding. It has also been reported that re-bleeding was associated with worse VA and higher complication rates..$^{[1,22,27,29-31]}$ In our study, grade of disease, VA and complication rates were similar in patients with and without re-bleeding. The rate of re-bleeding was lower in our study. This may be due to hospitalization of all patients, immobilization by bed rest, topical steroid use, lack of sickle cell anemia, and being of Caucasian race.

In conclusion, visual prognosis was found to be negatively affected by the presence of additional ocu- lar pathologies in grade 3 and 4 traumatic hyphema patients. Grade 4 patients had lower initial and final VA, higher IOP levels and a higher surgery rate with respect to grade 3 patients. There were no significant correlations between the etiologic factors and VA, IOP, accompanying findings, complications, or surgery rates. Serious complications were seen in $49 \%$ of all patients. VA was less then 0.5 in $15 \%$ and less then 0.1 in $6 \%$ of the patients. Close follow-up and appropriate treatment in patients with serious hyphema may reduce complications and improve the negative course of the disease.

Conflict-of-interest issues regarding the authorship or article: None declared.

\section{REFERENCES}

1. Walton W, Von Hagen S, Grigorian R, Zarbin M. Management of traumatic hyphema. Surv Ophthalmol 2002;47:297334.

2. Pearlman JA, Au Eong KG, Kuhn F, Pieramici DJ. Airbags and eye injuries: epidemiology, spectrum of injury, and analysis of risk factors. Surv Ophthalmol 2001;46:234-42.

3. Lai JC, Fekrat S, Barrón Y, Goldberg MF. Traumatic hyphema in children: risk factors for complications. Arch Ophthalmol 2001;119:64-70.

4. Strahlman E, Elman M, Daub E, Baker S. Causes of pediatric eye injuries. A population-based study. Arch Ophthalmol 1990;108:603-6.

5. Karg1 SH, Demirbay P, Özdal P, Yarpuz IM, Caliskan B, Teke $M$ ve ark. Künt göz travmalarının klinik değerlendirilmesi. T Oft Gaz 2002;32:863-8.

6. Wilson FM. Traumatic hyphema. Pathogenesis and management. Ophthalmology 1980;87:910-9.

7. Wong TY, Tielsch JM. A population-based study on the incidence of severe ocular trauma in Singapore. Am J Ophthalmol 1999;128:345-51.

8. Canavan YM, Archer DB. Anterior segment consequences of blunt ocular injury. Br J Ophthalmol 1982;66:549-55.

9. Shiuey Y, Lucarelli MJ. Traumatic hyphema: outcomes of outpatient management. Ophthalmology 1998;105:851-5.

10. Campbell DG. Ghost cell glaucoma following trauma. Ophthalmology 1981;88:1151-8.

11. Agapitos PJ, Noel LP, Clarke WN. Traumatic hyphema in children. Ophthalmology 1987;94:1238-41.

12. DeRespinis PA, Caputo AR, Fiore PM, Wagner RS. A survey of severe eye injuries in children. Am J Dis Child 1989;143:711-6.

13. Farber MD, Fiscella R, Goldberg MF. Aminocaproic acid versus prednisone for the treatment of traumatic hyphema. A randomized clinical trial. Ophthalmology 1991;98:279-86.

14. Spoor TC, Kwitko GM, O’Grady JM, Ramocki JM. Traumatic hyphema in an urban population. Am J Ophthalmol 1990;109:23-7.

15. Ashaye AO. Traumatic hyphaema: a report of 472 consecutive cases. BMC Ophthalmol 2008;8:24.

16. Ng CS, Strong NP, Sparrow JM, Rosenthal AR. Factors related to the incidence of secondary haemorrhage in 462 patients with traumatic hyphema. Eye (Lond) 1992;6:308-12.

17. Fong LP. Secondary hemorrhage in traumatic hyphema. Predictive factors for selective prophylaxis. Ophthalmology 1994;101:1583-8. 
18. Baker RS, Wilson MR, Flowers CW Jr, Lee DA, Wheeler NC. Demographic factors in a population-based survey of hospitalized, work-related, ocular injury. Am J Ophthalmol 1996;122:213-9.

19. Rakusin W. Traumatic hyphema. Am J Ophthalmol 1972;74:284-92.

20. Kearns P. Traumatic hyphaema: a retrospective study of 314 cases. Br J Ophthalmol 1991;75:137-41.

21. Kennedy RH, Brubaker RF. Traumatic hyphema in a defined population. Am J Ophthalmol 1988;106:123-30.

22. Mela EK, Dvorak GJ, Mantzouranis GA, Giakoumis AP, Blatsios G, Andrikopoulos GK, et al. Ocular trauma in a Greek population: review of 899 cases resulting in hospitalization. Ophthalmic Epidemiol 2005;12:185-90.

23. Jan S, Khan S, Mohammad S. Hyphaema due to blunt trauma. J Coll Physicians Surg Pak 2003;13:398-401.

24. Macewen CJ. Eye injuries: a prospective survey of 5671 cases. Br J Ophthalmol 1989;73:888-94.
25. Read J, Goldberg MF. Comparison of medical treatment for traumatic hyphema. Trans Am Acad Ophthalmol Otolaryngol 1974;78:799-815.

26. Kaufman JH, Tolpin DW. Glaucoma after traumatic angle recession. A ten-year prospective study. Am J Ophthalmol 1974;78:648-54.

27. Salvin JH. Systematic approach to pediatric ocular trauma. Curr Opin Ophthalmol 2007;18:366-72.

28. Crouch ER Jr, Frenkel M. Aminocaproic acid in the treatment of traumatic hyphema. Am J Ophthalmol 1976;81:35560 .

29. Edwards WC, Layden WE. Traumatic hyphema. A report of 184 consecutive cases. Am J Ophthalmol 1973;75:110-6.

30. Amoni SS. Traumatic hyphaema in Kaduna, Nigeria. Br J Ophthalmol 1981;65:439-44.

31. Abraham DI, Vitale SI, West SI, Isseme I. Epidemiology of eye injuries in rural Tanzania. Ophthalmic Epidemiol 1999;6:85-94. 